\title{
ANALYSIS, DESIGN AND APPLICATIONS OF ROTATIONAL FRICTION DAMPERS FOR SEISMIC PROTECTION
}

\begin{abstract}
The paper introduces the basic types of damping devices and summarizes the benefits of implementing supplemental damping systems for seismic protection of buildings and other structures. A novel damper device based on the rotational friction hinge concept invented by the first author is described. The slip capacity of the device and its energy dissipation capacity can be easily increased by adding more layers of steel plates and friction pads. The experimental evaluation of the original damper unit was first carried out in DTU, Denmark under displacement and forcing frequency control. The friction pads were made from advanced material capable of sustaining up to 400 cycles without property degradation. In 2001, an international team including the authors conducted intensive research program on a three-storey building equipped with rotational friction dampers at the largescale shake-table testing facility of the NCREE, Taiwan. The performance of the damped structure was examined for 14 cases of seismic input with peak ground acceleration (PGA) varying from $0.05 \mathrm{~g}$ to $0.30 \mathrm{~g}$. The testing demonstrated the remarkable efficiency of the damping system for reducing the lateral displacements and interstorey drifts of the test building. Nonlinear time-history analyses were used for predicting the dynamic response of the structure and selecting adequate damper capacities. A few representative applications of RFDs for seismic protection of buildings and facilities in Europe and Japan are given which demonstrate the reliability of the devices and their most typical arrangements within new and existing structures. It is concluded that the displacementdependent dampers such as friction and metallic are a powerful and nonexpensive engineering tool for solving vibrational problems both in new and existing structures.
\end{abstract}

Keywords: seismic resistance, passive energy dissipation, supplemental damping systems, experimental testing, nonlinear analysis

\footnotetext{
${ }^{1}$ Author for correspondence: Borislav Belev, University of Architecture, Civil Engineering and Geodesy, Sofia, 1 Hr. Smirnenski Blvd.Sofia 1046, Bulgaria, Ph. (+ 359 2) 963 52 45/336: e-mail: belev_fce@uacg.bg.

2 Imad Mualla, CTO, Damptech, Brovej Building 118, DK-2800 Kgs. Lyngby, Denmark, ph. +45 452517 25, e-mail: ihm@byg.dtu.dk.
} 


\section{Introduction}

The conventional approach in earthquake-resistant design employs the structural ductility and related plastic deformations of structures under strong earthquakes for dissipating a major part of the seismic input energy. The seismic protection is a more advanced alternative approach which aims at reducing significantly or completely eliminating the ductility demand and related damage to the primary structural members. According to the classification of Soong and Dargush [6], three major structural protective systems could be employed for the purpose -seismic (base) isolation, passive energy dissipation, and semi-active/active control systems. Damper devices of different types could be used in any of these three options, but typically they are the key component of the passive energy dissipation systems (damping systems). Depending on the response of the dampers to imposed relative displacements and/or relative velocities at their ends, three major types of devices are available according to the classification of FEMA 273 [4]: (a) displacement-dependent devices (e.g. metallic dampers and friction dampers); (b) velocity-dependent dampers (fluid viscous dampers, solid visco-elastic dampers, etc.); and (c) other types (shape-memory alloys, self-centering devices, etc.). Comprehensive details of the energy-dissipation mechanism and mathematical modelling of these devices could be found elsewhere [4,5]. Chapter 15 of FEMA 450 [5] contains provisions for the design of structures with damping systems.

It is believed that the implementation of a supplemental damping adds a lot of merits and advantages. In new-built buildings and facilities it will improve the overall seismic performance in terms of reduced ductility demands, which implies less damage to structural and non-structural components and more economical design. While the ductility of the conventional structures is exhausted following a major earthquake, a building/facility with a properly designed damping system will better preserve its energy dissipation capacity and will not be vulnerable to the expected aftershocks. When applied to seismic upgrade of existing structures, the passive energy dissipation approach could be a viable and time-saving alternative to the conventional retrofit measures such as casting new RC shear walls, and an efficient engineering tool for correcting irregularities, suppressing torsional response, etc.

\section{Description and features of the Rotational Friction Damper (RFD)}

The original configuration of the rotational friction damper (RFD) consists of steel plates clamped together by a prestressed steel bolt to form a T-shaped device. In-between the steel plates circular friction pad discs made of high-tech composite material are inserted. In order to maintain a constant pressure at the friction interfaces several disc springs, external steel plates and hardened wash- 
ers are used. The slip capacity of the device and its energy dissipation potential can be easily increased by adding more layers of steel plates and friction pads. The energy dissipation of the T-damper depends on the sliding moment Ms and the sliding rotation angle $\theta$ between the vertical and horizontal plates. The T-shaped device and its idealized moment-rotation relationship are shown in Fig. 1.

Complete description of the device and review of parameters influencing the dynamic response of structures with friction dampers along with discussion of efficiency criteria can be found in [1].
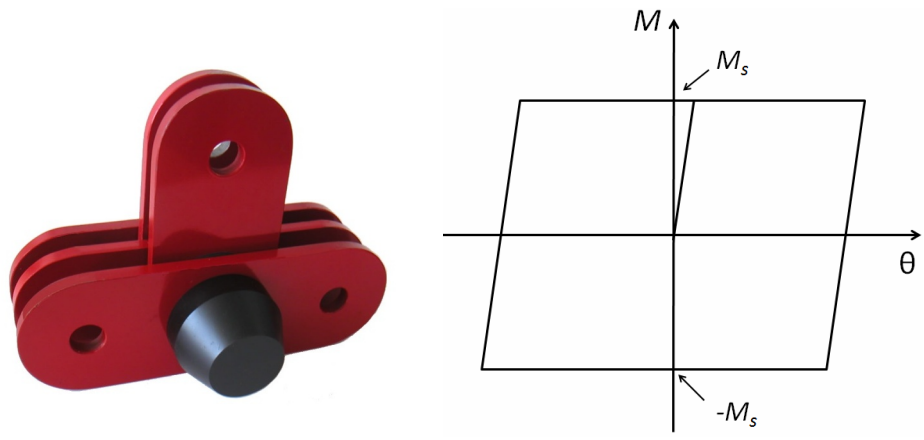

Fig. 1. Original T-shaped friction damper and its idealized moment-rotation relationship

Rys. 1. Oryginalny Teowy tłumik cierny i jego wyidealizowana zależność moment - obrót

The simplest installation of the device in a single storey frame is illustrated in Fig. 2. The vertical plates are connected to the girder by a pin connection. The horizontal plates are connected to the column bases by steel bracing members. If tension-only braces are used, a prestressing is needed to prevent them from buckling.

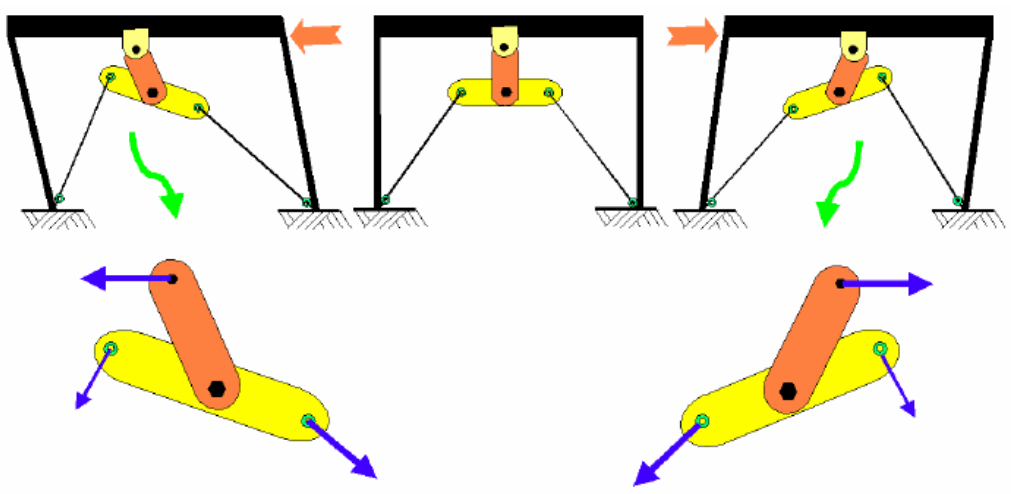

Fig. 2. Arrangement of T-shaped friction damper in a single-storey frame Rys. 2. Układ Teowego tłumika ciernego w ramie jednokondygnacyjnej 
Further development and commercial supply of RFDs with improved configurations and broad range of slip capacities are now provided by Damptech AS based in Technical University of Denmark (DTU). Fig. 3 displays one of the largest RFDs with slip capacity of $5000 \mathrm{kN}$ during its cyclic testing in DTU lab.
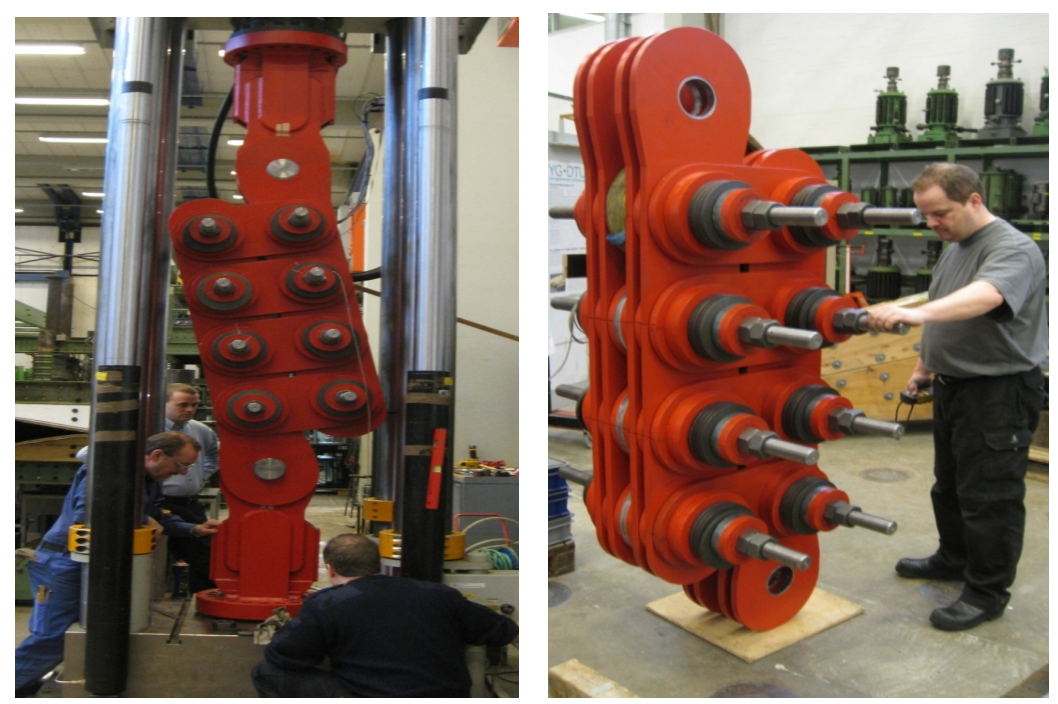

Fig. 3. Testing of large capacity RFD in DTU lab

Rys. 3. Badania thumika obrotowo-ciernego dużej mocy RFD w laboratorium DTU

The displacement-dependent dampers (metallic dampers, friction devices, etc.) are relatively cheap, durable and show well-defined (predictable) response so that the primary frame and brace members can be safely designed using capacity design procedures. However, their response is nonlinear which complicates the analysis. These dampers depending on their locations within the primary structure may be sensitive to temperature effects and long-term deformations (shrinkage, creep, etc.). The metallic dampers, in particular, may have potential low-fatigue problems, while some friction dampers may suffer from degradation of the contact surfaces and variation of the coefficient of friction over time.

\section{Most significant results from experimental and numerical re- search on structures with RFDs}

The experimental evaluation of a damper unit was first carried out in DTU under displacement and forcing frequency control. The friction pads were made from material capable of sustaining up to 400 cycles without property degradation. The damper was inserted in a $1 / 3$ scale portal frame model through in- 
verted-V brace and subjected to harmonic lateral loading applied at the girder end. This testing revealed that the device was almost frequency-independent within the $2-7 \mathrm{~Hz}$ range of forcing frequency and the amount of dissipated energy per cycle was proportional to the displacement amplitude. Those findings justify the use of the Coulomb law for friction modelling and imply that the RFD can be classified as displacement-dependent according to Chapter 9 of FEMA 273 [4].

In 2001, an international team including the authors conducted intensive research program on a three-storey building equipped with RFDs at the advanced large-scale shake-table testing facility of the NCREE, Taiwan. The test building was a steel moment-resisting frame structure with $3.0 \mathrm{~m}$ storey height and $4.5 \mathrm{~m}$ bay width in the direction of shaking (Fig. 4). The columns were fixed at their bases and the beam-to-column joints were fully welded. Due to the fact that the columns were bent about the weak axis of their cross section, the structure (without dampers and bracing) was relatively flexible in the direction of testing with estimated fundamental period of vibration $T_{l}=0.936 \mathrm{~s}$. Heavy concrete blocks were used to simulate the floor weights. The total mass of the building including the auxiliary base perimeter frame measured by weighing was 38.3 tons.

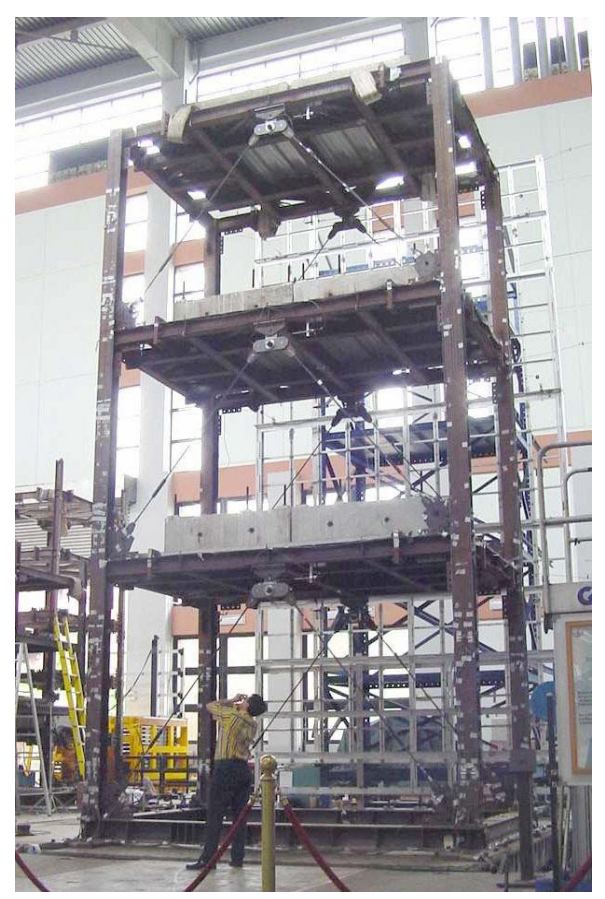

Fig. 4. Shake-table testing of steel structure equipped with RFDs in NCREE lab (Taipei, Taiwan)

Rys. 4. Badania na stole wibracyjnym stalowej konstrukcji wyposażonej w RFDs w laboratorium NERCE (Taipei, Tajwan) 
It was decided to use several earthquake records of far-field and near-fault types from the 1940 Imperial Valley - El Centro (USA), 1995 Kobe (Japan) and 1999 Chi-chi (Taiwan) events. The performance of the damped structure was examined for 14 cases of seismic input with peak ground acceleration (PGA) varying from $0.05 \mathrm{~g}$ to $0.30 \mathrm{~g}$. Several arrangements of the damper slip resistance along the height of the building were used but each arrangement was kept unchanged for a couple of tests of different intensity. For example, the Kobe Takatori record was first applied with PGA $=0.1 \mathrm{~g}$ followed by consecutive shaking with PGA of $0.05 \mathrm{~g}, 0.15 \mathrm{~g}$ and $0.175 \mathrm{~g}$ without readjusting the bolt clamping forces and device slip capacities. This was a kind of simulation of a series of quakes including aftershocks and could be also viewed upon as a possible situation in which damper parameters deviating from the design ones were introduced due to a mistake of the installing staff. None of the friction pads or other RFD components were damaged or replaced during the series of 14 tests.

The further tests with stronger ground shaking $(\mathrm{PGA}=0.15 \mathrm{~g}-0.30 \mathrm{~g})$ demonstrated the remarkable efficiency of the damping system in reducing the lateral displacements and interstorey drifts of the test building by 70 to $80 \%$. More detailed information on the testing carried out in NCREE and its results can be found in [2] and [3].

Finite element models of the bare and friction-damped frames were created prior to the experimental program in order to support the planning of the shaketable test. The friction action of the RFD was conventionally modelled by nonlinear spring with rigid-plastic moment-rotation relationship. At this stage the emphasis was placed on choosing adequate brace stiffness and damper slip capacities that would provide good performance under the records considered for seismic input. The major constraint was the requirement to limit the interstorey drifts up to $2 \mathrm{~cm}(1 / 150$ of the storey height) in order to protect the test frame structure from plastic deformation and damage. An important indicator for the efficiency of the damping system in these preliminary analyses was the amount of energy dissipated in sliding friction as a percentage of the total input energy fed into the structure by the ground shaking. The modal damping ratios for the first and second modes of vibration were set to $1.5 \%$ and $0.5 \%$ respectively, as indicated by other researchers that had previously used the same test building. The experimentally obtained and predicted by nonlinear timehistory analysis roof displacement histories are plotted in Fig. 5. Their comparison shows that good agreement between the measured and simulated response was achieved. However, this agreement was reached only after the effects of the beam-to-column joint semi-rigidity of the primary steel frames were included in the finite element model. 


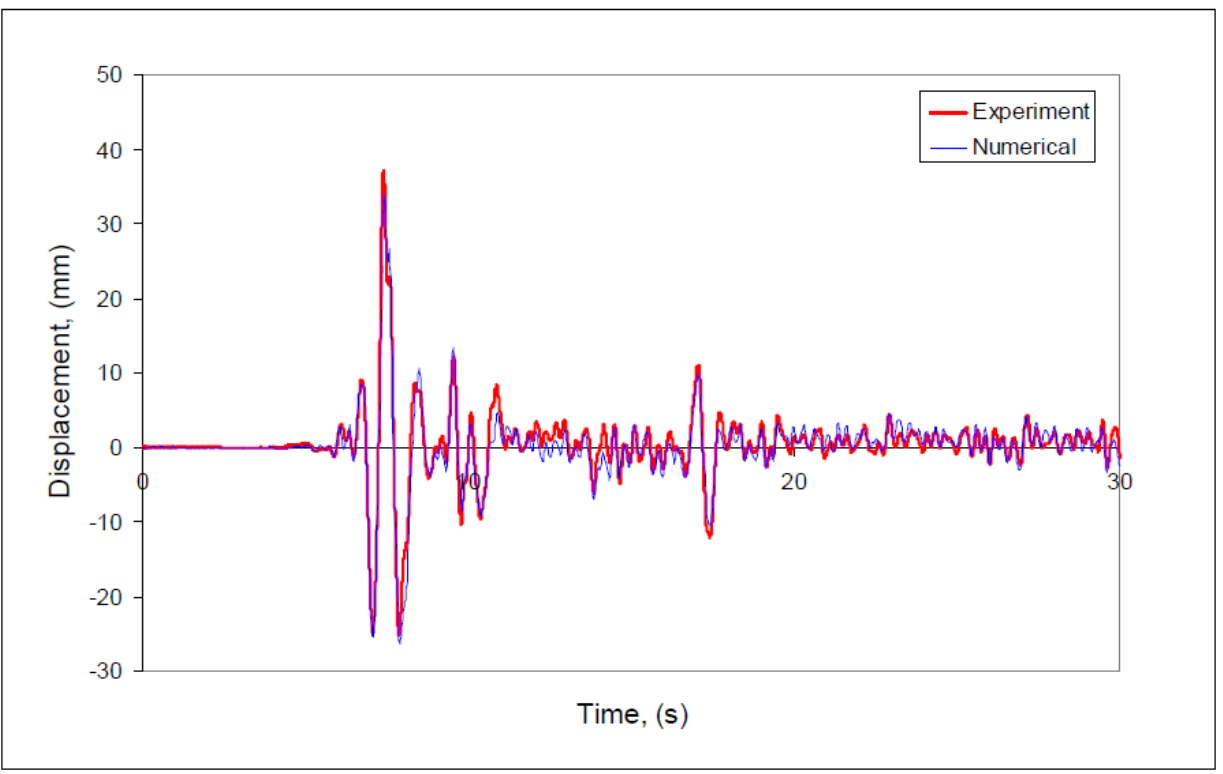

Fig. 5. Roof displacement histories for the damped frame under El Centro 0.20g seismic input

Rys. 5. Wykres przemieszczeń stropu ramy tłumionej poddanej działaniu obciążenia sejsmicznego El Centro 0.20g

Testing of damper units of various slip capacity has been systematically carried out prior to their shipment to the respective project sites in order to confirm the specified properties of the devices. A typical force-displacement relationship for a RFD with $100 \mathrm{kN}$ slip capacity is shown in Fig. 6.

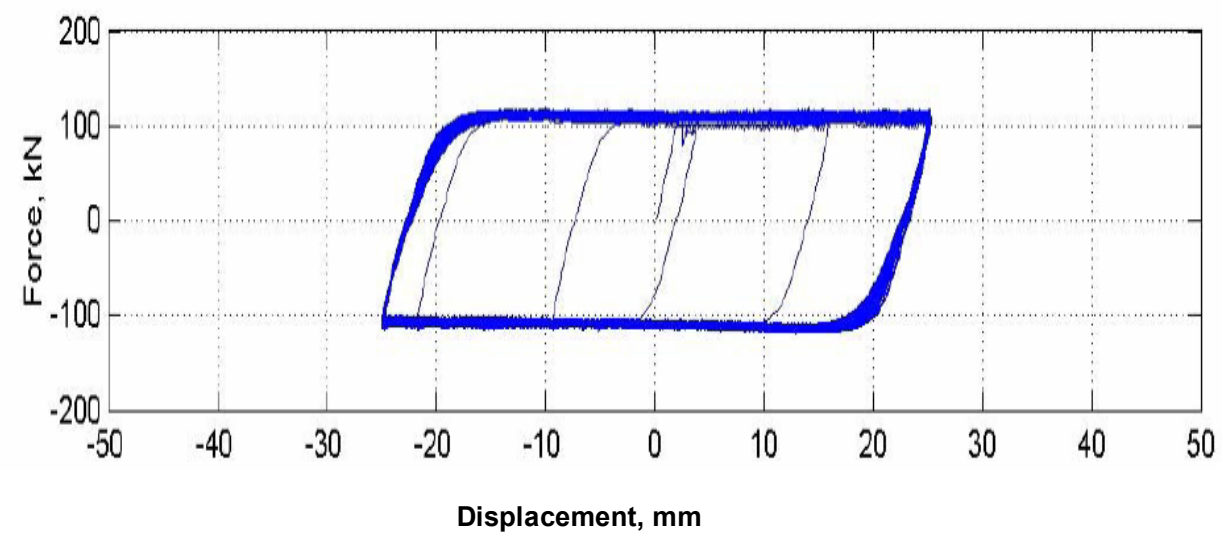

Fig. 6. Force-displacement response of a typical RFD under cyclic loading Rys. 6. Odpowiedź siła - przemieszczenie typowego RFD poddanego obciążeniu cyklicznemu 


\section{Applications of RFDs for seismic protection of buildings and other structures}

One of the first applications of the friction damper devices was in two old temple buildings with timber structure in Japan. Both temples had a soft basement and by adding dampers and bracings both stiffness and supplemental damping were added by the dampers. The first temple with RFD devices was the Yagurji Temple (Fig. 7).
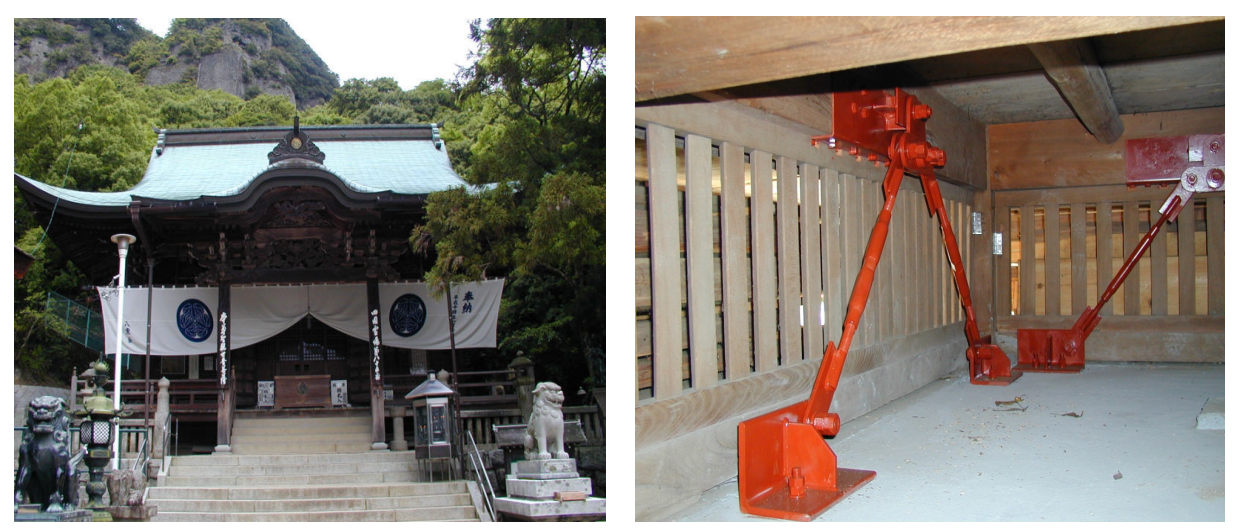

Fig. 7. Installation of RFD devices in Japanese temple (according to [7])

Rys. 7. Zamontowane urządzenia RFD w Japońskiej świątyni (na podstawie [7])

The passive energy dissipation concept was implemented by the authors for the seismic protection of an industrial facility in Greece which had to be erected over an existing RC substructure. The design PGA for the site was $0.24 \mathrm{~g}$. The design objective was to reduce the design base shear to levels below $1120 \mathrm{kN}$, for which the supporting RC sub-structure was originally designed. Preliminary calculations indicated that a conventional steel structure with inverted-V braces was inappropriate due to the very high base shear (estimated to $3000 \mathrm{kN}$ according to the local design code). The design solution involved RFDs of small slip capacity (50-60 kN per device), which resulted in total slip capacity per each major direction smaller than $600 \mathrm{kN}$. The initially designed chevron braces were modified in order to install pairs of V-shaped damper devices (Fig. 8). 


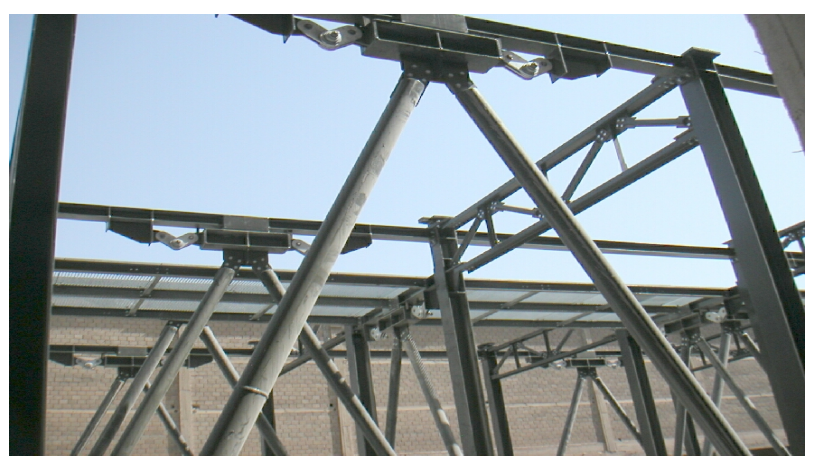

Fig. 8. Steel structure of industrial facility with V-shaped friction dampers

Rys. 8. Konstrukcja stalowa obiektu przemysłowego z thumikami ciernymi w kształcie litery V

The seismic response was evaluated by nonlinear time-history analyses using three sets of appropriately scaled ground acceleration histories. The results revealed that the columns experienced bending moments larger that initially estimated and in order to satisfy the resistance checks with the original cross sections of the steel members, higher steel grade was specified for the columns and the beams to which damper devices were attached.

Rotational Friction Dampers (supplied by Damptech of Denmark) have been also used in several base-isolated buildings. Seismic (base) isolation is a protection technique for buildings and other structures which reduces significantly the seismic energy input and related seismic shear forces and interstorey drifts. The first project where Damptech dampers were used in base isolation system was in a five-storey laboratory building in Japan (Fig. 9). For this project V-shaped friction dampers with high displacement capacity were fabricated and tested at DTU. Two other projects with base isolation system including Damptech dampers were a 12-storey apartment building in Tokyo and a 7-storey laboratory building in Yokohama.
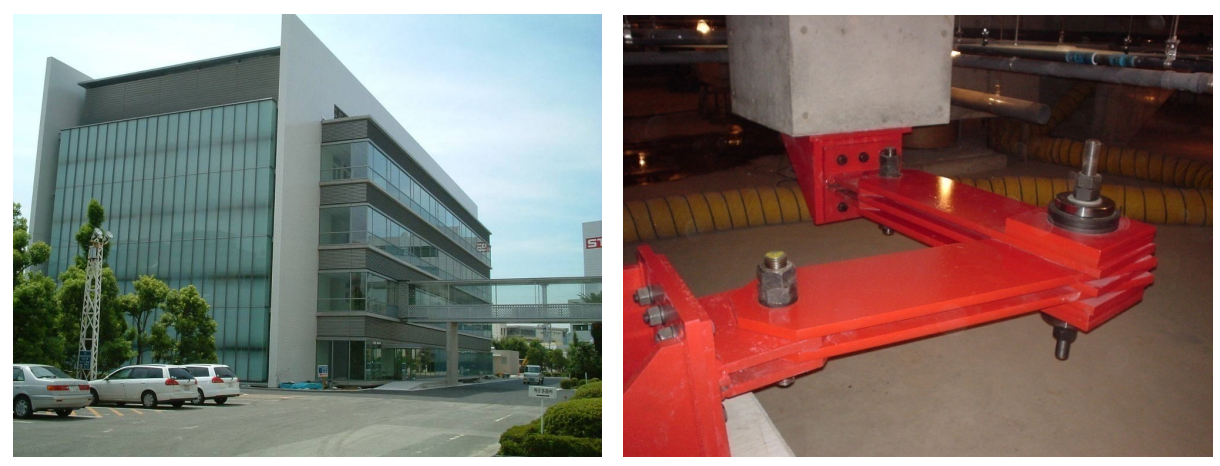

Fig. 9. Five-storey building in Japan with base isolation incorporating RFDs

Rys. 9. Pięciokondygnacyjny budynek w Japonii z izolacją podstaw słupów połączoną z RFDs 
After the successful application of RFD devices for base isolation of lowand medium-rise buildings it was decided to use them in high-rise buildings, too. The first high-rise building equipped with Damptech dampers of base isolation type was a 44-storey residential tower in Osaka.

Dampers of large slip capacity were delivered to Takenaka Corp., one of largest Japanese construction companies, for the tallest building in Japan with a height of $300 \mathrm{~m}$. The project was called "Abeno Harukas Building". According to the design layout the dampers were installed in combination with V-braces (Fig. 10). In order to reach the target slip capacity of $1500-2250 \mathrm{kN}$ the dampers were designed with four friction joints and several layers of steel plates and friction pads. For the approval procedure device prototypes were tested both in DTU and Japanese test facilities (Fig. 11, left). The installation on site is shown in Fig. 11, right.

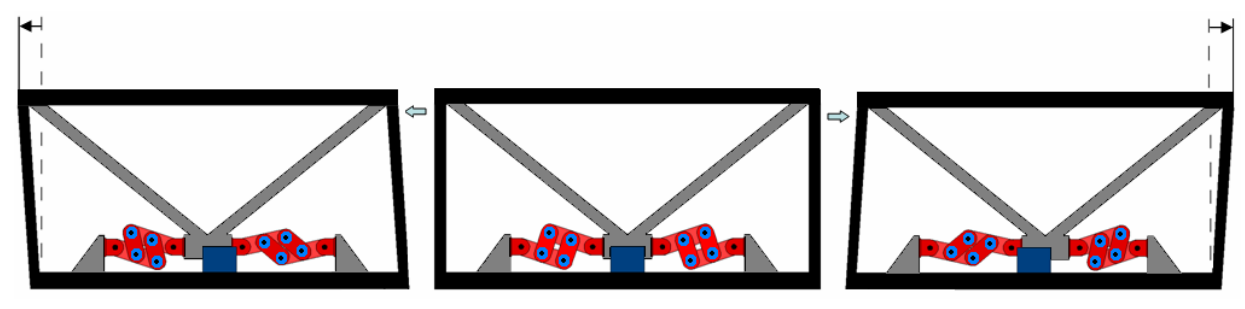

Fig. 10. Typical arrangement of RFDs in tallest building in Japan

Rys. 10. Typowy układ RFDs w najwyższym budynku w Japonii
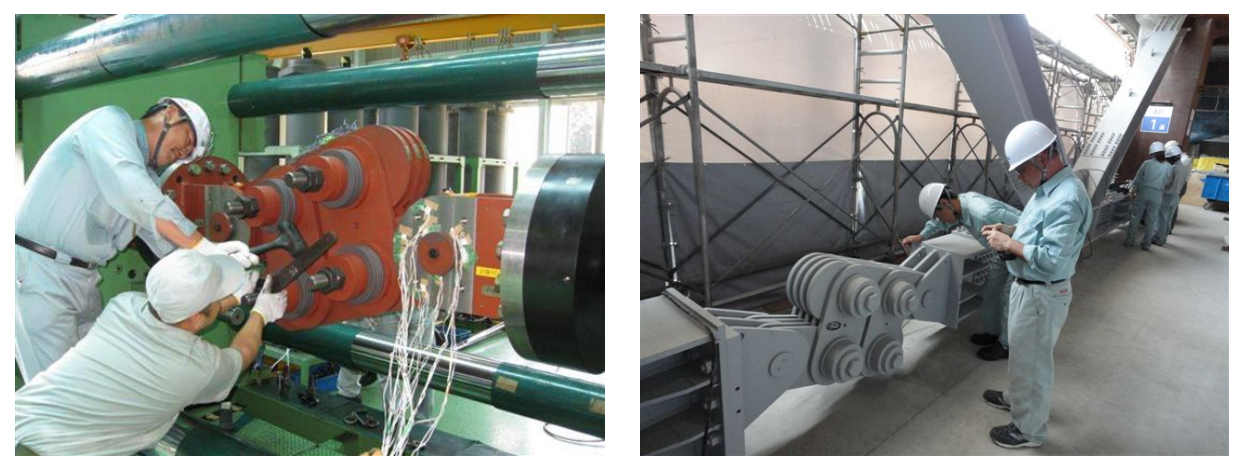

Fig. 11. Prototype test set-up (left) and completed installation of large capacity dampers in Japan (right)

Rys. 11. Badanie prototypu (po lewej) i pełna instalacja tłumików dużej mocy w Japonii (po prawej)

Other applications of RFDs include industrial facilities and power plants were they have been successfully used for reducing machine-induced vibrations. More information on the topic can be found in [7]. 


\section{Conclusions}

Based on the publications on passive energy dissipation (damping systems) for seismic protection and presented results of our own research and design, the following conclusions could be drawn:

- the passive damping systems are now a mature and reliable technology for seismic protection;

- the application of displacement-dependent damping devices (friction and metallic dampers) require increased analysis and design efforts but could be a powerful and non-expensive engineering tool for solving vibrational problems both in new and existing structures;

- the friction dampers such as RFDs offer certain advantages which could be fully exploited if a proper system of supporting members is provided;

- the rigorous full-scale testing at the shake table facility of NCREE, Taiwan proved the excellent capability of the proposed damping system to significantly reduce earthquake-induced building vibrations.

- the worldwide acceptance and numerous applications of the RFD concept are a stimulating recognition for the research and development activities carried out by the authors of this paper over the last fifteen years.

\section{Bibliography}

[1] Mualla I.H., Belev B. Performance of steel frames with a new friction damper device under earthquake excitation. Engineering Structures, vol. 24(3), pp. 365-371.

[2] Mualla I.H., Nielsen L.O., Belev B., Liao W.I., Loh C.H., Agrawal A. Performance of friction-damped frame structure: shaking table testing and numerical simulations. Proceedings of 7th US National Conference on Earthquake Engineering, Boston, USA, 2002, vol. I, pp. 287-294.

[3] Mualla I.H., Nielsen L.O., Belev B., Liao W.I., Loh C.H., Agrawal A. Numerical predictions of shaking table tests on a full-scale friction-damped structure. Proceedings of 12th European Conference on Earthquake Engineering, London, 2002. Elsevier, paper 190.

[4] NEHRP Guidelines for the seismic rehabilitation of buildings (FEMA 273). FEMA, Washington D.C., 1997.

[5] NEHRP Recommended provisions for seismic regulations for new buildings and other structures, 2003 Edition, (FEMA 450). FEMA, Washington D.C., 2004.

[6] Soong T.T., Dargush G.F. Passive energy dissipation systems in structural engineering. Wiley \& Sons, 1997.

[7] http://www.damptech.com [access: 2 April 2015 r.] 


\section{ANALIZA, PROJEKTOWANIE I APLIKACJA OBROTOWO CIERNYCH TLUMIKÓW DLA OCHRONY SEJSMICZNEJ}

\section{Streszczenie}

W artykule przedstawiono podstawowe typy urządzeń tłumiących i podsumowano korzyści z zastosowania dodatkowych systemów tłumiących w celu sejsmicznej ochrony budynków i innych konstrukcji. Opisano nowatorskie urządzenie thumiące, wymyślonego przez pierwszego autora, bazujące na koncepcji tarcia obrotowego w przegubie. Zdolność do poślizgu urządzenia i jego zdolność do dyssypacji energetycznej może być łatwo zwiększana przez dodawanie kolejnych warstw blach stalowych i podkładek ciernych. Doświadczalna ocena prototypu urządzenia thumiącego, pod kątem przemieszczeń i częstości drgań wymuszonych, została przeprowadzona $\mathrm{w}$ DTU, w Danii. Podkładki cierne zostały wykonane z zaawansowanego technologicznie materiału zdolnego wytrzymać do 400 cykli obciążenia bez degradacji swoich właściwości. W 2001 roku międzynarodowy zespół, w skład którego wchodzili również autorzy, przeprowadził intensywny program badawczy na trzykondygnacyjnym budynku, wyposażonym w thumiki obrotowo cierne na stole wibracyjnym dużej skali obiekcie testowym NCREE, na Tajwanie. Przygotowaną Konstrukcję z thumikami badano dla 14 przypadków obciążeń sejsmicznych ze szczytowymi wartościami przyśpieszenie ziemi (PGA) w granicach 0.05 g do $0.30 \mathrm{~g}$. Badania wykazały niezwykłą efektywność systemu thumiącego $\mathrm{w}$ redukcji giętnych przemieszczeń i przesunięć międzykondygnacyjnych w badanym budynku. Do określenia odpowiedzi dynamicznej konstrukcji i dobrania odpowiedniej mocy tłumika zostały użyte nieliniowe analizy przebiegów czasowych. Zaprezentowano kilka przykładowych zastosowań RFDs w celu sejsmicznego zabezpieczenia budynków i obiektów w Europie i Japonii, wykazując niezawodność urządzeń i ich najbardziej typowe układy wewnątrz nowych i istniejących budynków. Na koniec stwierdzono, że tłumiki związane z przemieszczeniami takimi jak tarcie są potężnym i niedrogim narzędziem inżynierii dla rozwiązywania problemów drgań zarówno w nowych jak i istniejących konstrukcjach.

Keywords: nośność sejsmiczna, dyssypacja energii pasywnej, dodatkowy system thumienia, badania doświadczalne, analiza nieliniowa

Przestano do redakcji:30.05.2015

Przyjęto do druku:10.01.2016

DOI: $10.7862 / \mathrm{rb} .2015 .199$ 